\title{
Detection of chromosomal aberrations by comparative genomic hybridization during transformation of human breast epithelial cells in vitro
}

\author{
G.A. BALOGH ${ }^{1}$, I.H. RUSSO ${ }^{1}$, B.R. BALSARA ${ }^{2}$ and J. RUSSO ${ }^{1}$ \\ ${ }^{1}$ Breast Cancer Research Laboratory, ${ }^{2}$ Human Genetics Program, \\ Fox Chase Cancer Center, Philadelphia, PA 19111, USA
}

Received March 10, 2006; Accepted May 25, 2006

\begin{abstract}
Breast cancer is the most frequent malignancy in women. It is well recognized that tumorigenesis is a multistep process resulting from the accumulation of sequential genetic alterations. In breast cancers $\mathrm{LOH}$ has been described on one or both arms of multiple chromosomes. Comparative genomic hybridization ( $\mathrm{CGH}$ ) analysis was performed to identify chromosomal imbalances in the breast epithelial cells (HBEC). We have used a human in vitro-in vivo system in which the environmental carcinogen benz(a)pyrene (BP) and the c-Ha-ras oncogene were utilized for inducing in vitro transformation of HBEC. Immortal MCF-10F cells were treated with BP which resulted in the transformed cell line BP-1 that was further enhanced by transfection with the cHa-ras to generate the cell line BP-1-Tras. This cell line is tumorigenic when injected in severe combined immunodeficient (SCID) mice, generating the tumor cell line BP-1Tras T J\#4. Our comparative genomic hybridization analysis indicates that the most overrepresented segment after cell transformation and in the BP-1, BP-1-Tras and in the tumor cell line were 1p (80\%), 5q21-ter (80\%), 8q24.1 (90\%) and Xq27-28 (60\%). DNA sequence amplification at 10p14-15 was observed in BP-1-Tras T J\#4 cells. Allelic losses of chromosome 4,8p11-21 and 15q11-12, occur after cell transformation and are maintained consistently during tumorigenesis.
\end{abstract}

\section{Introduction}

Many genomic alterations, such as DNA amplification and loss of genetic material, which may involve tumor suppressor

Correspondence to: Dr Jose Russo, Breast Cancer Research Laboratory, Fox Chase Cancer Center, 333 Cottman Avenue, Philadelphia, PA 19111, USA

E-mail: j_russo@fccc.edu

Key words: comparative genomic hybridization, cell transformation, MCF-10F, benz(a)pyrene, c-Ha-ras genes, have been found in breast cancer in at least 11 chromosomes (1-18). The detection of these genetic alterations in various tumor stages has provided evidence that primary and secondary events accumulate and hence contribute to stepwise neoplastic progression. The fact that the alterations are complex makes it difficult to precisely determine whether these genomic changes are responsible for the initiation and/or the progression of the disease, or whether they are the consequence of chromosomal destabilization caused by tumor cell proliferation $(17,18)$. It is expected that specific types of genetic alterations identify essential steps in the initiation and/or progression of cancer. We used comparative genomic hybridization ( $\mathrm{CGH}$ ), a technique that has been utilized extensively to document both genetic gains and losses in human cancer, for determining whether somatic genetic aberrations occurred in our in vitro-in vivo system that recapitulates the initiation and progression of the disease (19-21). In our model, transformation of the normal immortalized human breast epithelial cells (HBEC) MCF-10F $(22,23)$ was induced by in vitro treatment with the chemical carcinogen benz(a)pyrene (B[a]P) (24). After clonal selection the cells exhibited anchorage-independent growth, colony formation in agar methocel, and loss of ductulogenic capacity in collagen gel. c-Ha-ras transfection intensified the expression of transformation phenotypes, generating BP-1-Tras, a tumorigenic cell line (25). Injection of these cells to severe combined immunodeficient (SCID) mice generated the tumor cell line BP-1-Tras T J\#4 (21). DNA analysis by comparative genomic hybridization (CGH) revealed that phenotypically transformed cells exhibited the same type of genomic alterations observed in spontaneous malignancies. A sequence of genomic changes was manifested during in vitro transformation and was maintained during the tumorigenesis process, with significant chromosomal losses on 4p/q and 15q11-12.

\section{Materials and methods}

Cell lines. For these experiments we used the spontaneously immortalized human breast epithelial cell line MCF-10F, its human breast epithelial origin has been confirmed by genetic, cytogenetic, ultrastructural, and phenotypic characteristics, which are identical to the mortal MCF-10M 


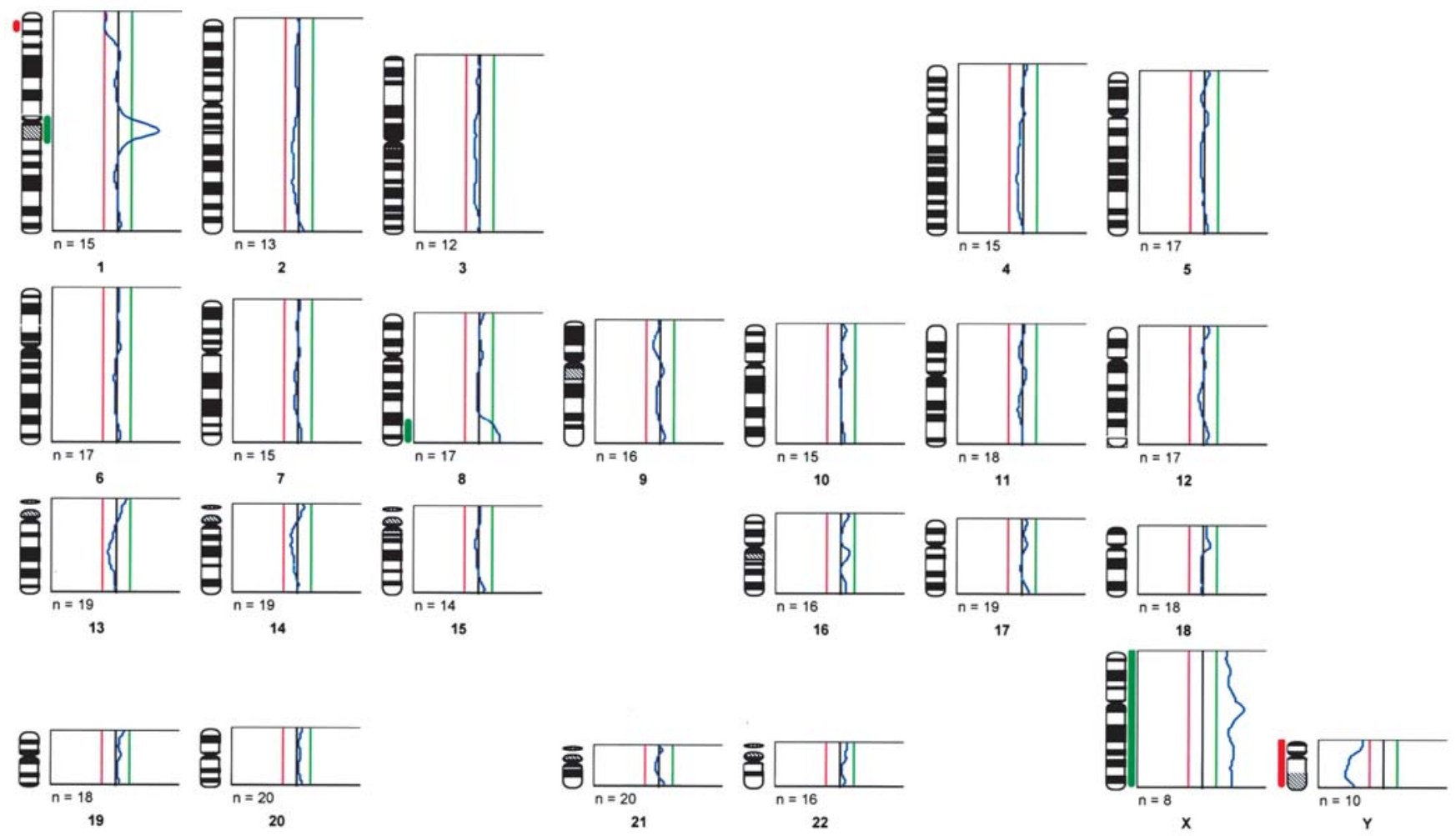

Figure 1. CGH profile of the MCF-10F cell line. The chromosomes and the gain and loss are indicated in green and red, respectively. The three vertical lines represent the balance state (control) and the lower (left) and the upper (right) thresholds used as diagnostic cutoff values for losses and gains, respectively.

cells from which they were derived, except for the fact that the immortal cells are pseudodiploid and express minimal chromosomal alterations $(22,23)$. We also used the B[a]P transformed tumorigenic cell line BP-1Tras (24) and the tumor-derived cell line BP-1-Tras J\#4 (21). All cell lines are cultured in our laboratory in DMEM medium under standard conditions at $37^{\circ} \mathrm{C}$ in a $\mathrm{O}_{2} / \mathrm{CO}_{2}$ atmosphere.

DNA isolation. DNA was extracted from the cells in culture when they were $70-80 \%$ confluent. The cells were treated with lysis buffer $(100 \mathrm{mM} \mathrm{NaCl}, 20 \mathrm{mM}$ Tris- $\mathrm{HCl} \mathrm{pH} 8.0$, $25 \mathrm{mM}$ EDTA pH 8.0,0.5\% SDS) and $200 \mu \mathrm{g} / \mathrm{ml}$ proteinase $\mathrm{K}$ was added and incubated at $65^{\circ} \mathrm{C}$ for $15 \mathrm{~min}$ with gentle agitation. The samples were cooled down on ice and treated with $100 \mu \mathrm{g} / \mathrm{ml} \mathrm{RNase}$ at $37^{\circ} \mathrm{C}$ for $30 \mathrm{~min}$. The DNA was purified with a phenol extraction $(\mathrm{pH} 8.0)$ followed by chloroform:isoamyl alcohol (24:1). The aqueous layer was adjusted to $0.75 \mathrm{M}$ with ammonium acetate and the DNA was precipitated with $100 \%$ ethanol. The samples were centrifuged, dried and dissolved in distilled water. The DNA was used for comparative genome hybridization (CGH).

Comparative genome hybridization (CGH). Protocols for DNA labeling and hybridization were performed as previously described (26). Gray-level images of fluorescence were captured with a Zeiss (Thorndale, NY) microscope connected to a cooled, charge-coupled-device camera (Photometrics, Tucson, AZ). Digital image analysis was performed using the Quips software (Vysis, Downers Grove, IL). The threshold was set at 0.8 and 1.2 for losses and gains, respectively. The mean values of individual ratio profiles were calculated from
Table I. Genetic imbalances in HBEC cells.

\begin{tabular}{lll}
\hline Cell line & \multicolumn{1}{c}{ Gains } & \multicolumn{1}{c}{ Losses } \\
\hline MCF-10F & $8 \mathrm{q} 24.1$ & \\
BP-1 & & \\
& $1 \mathrm{p}$ & 4 \\
& $5 \mathrm{q} 21-$ ter $8 \mathrm{q} 24$ & $8 \mathrm{p} 11-21$ \\
& $13 \mathrm{q} 33$ & $15 \mathrm{q} 11-12$ \\
& Xq27-28 & \\
BP-1-Tras & & \\
& $1 \mathrm{p}$ & 4 \\
& $5 \mathrm{q} 21-$ ter & $8 \mathrm{p} 11-21$ \\
& $8 \mathrm{q} 24.1$ & $15 \mathrm{q} 11-12$ \\
& $13 \mathrm{q} 33-34$ & \\
& Xq27-28 & \\
& & 4 \\
BP-1-Tras T J\#4 & $1 \mathrm{p}$ & $8 \mathrm{p} 11-21$ \\
& $5 \mathrm{q} 21-$ ter & $13 \mathrm{q} 11-13$ \\
& $6 \mathrm{q} 25-27$ & \\
& $8 \mathrm{q} 24.1$ & \\
& $18 \mathrm{q} 11.3$ & \\
& $\mathbf{2 0 p 1 1 , 2 0 q 1 3}$ & \\
& &
\end{tabular}

at least 7 metaphase spreads. Averaged values were plotted as profiles alongside individual chromosome ideograms. 

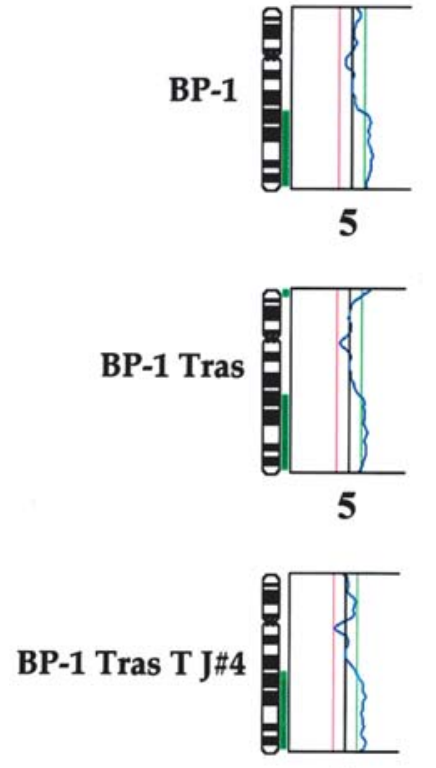

5

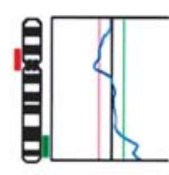

8

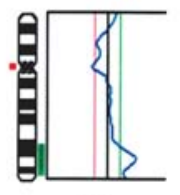

8

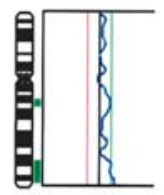

6

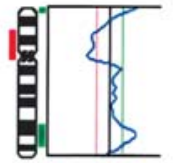

8

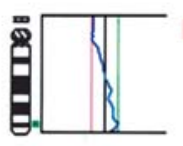

13

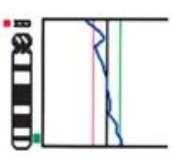

13

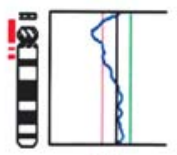

13
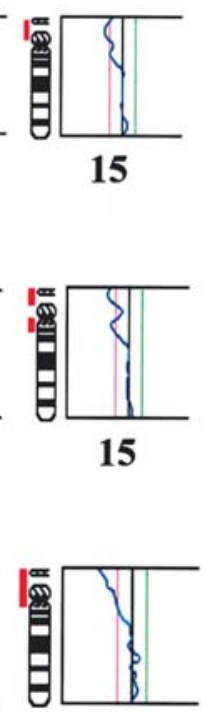

15
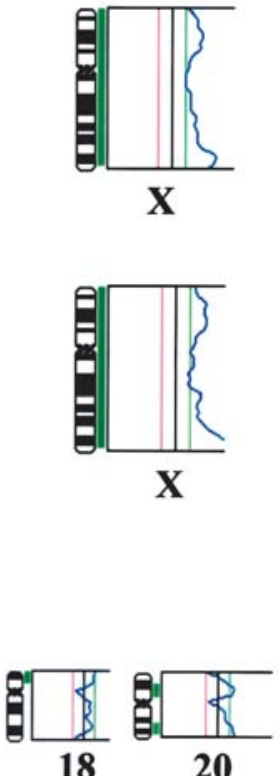

Figure 2. CGH profile of the transformed BP-1, BP-1-Tras and BP-1-Tras T J\#4 Cell lines.

\section{Results}

The immortal cell line (MCF-10F) showed a normal profile with gain only in the chromosome band 8q24 (Fig. 1). There are, however, multiple genomic alterations in the transformed, tumorigenic and tumor cell lines (Table I and Fig. 2). The transformed cell line BP-1 and the tumorigenic line BP-1-Tras had several more genomic imbalances compared to MCF$10 \mathrm{~F}$ cells. These include gains of $1 \mathrm{p}, 5 \mathrm{q} 21$-qter, $13 \mathrm{q} 33$, Xq27-28, amplification of 8q24, loss of chromosome 4, 15q11-12, and chromosome bands 8q11-21. Amplification at $8 \mathrm{q} 24.1$ was more pronounced in the tumorigenic cell line BP-1-Tras than in BP-1 cells. The tumor cell line had additional changes which include gains of $6 \mathrm{q} 25-27,18 \mathrm{p} 11.3$, 20p11 and 20q13, loss of chromosome bands 13q11-13 was also an additional change (Table I and Fig. 2). Allelic losses of chromosome 4,8p11-21 and 15q11-12, occur after cell transformation and are maintained consistently during tumorigenesis (Table I and Fig. 2).

\section{Discussion}

In the present work, using comparative genomic hybridization analyses, we observed that during the process of cell transformation and tumorigenesis the gains of DNA sequences were more common than losses, with the most frequent gains at 8q24.1, 1p, 5q21-ter, 13q33-34 and Xq37-38. Of significance is the loss of both arms of chromosome 4, 8p1121 and 15q11-12, which occur after cell transformation and were maintained consistently during the process of tumorigenesis involving one or more tumor suppressor genes which are frequently inactivated in several types of cancers.

The gain in the HBEC cells in the 8q24.1 was found in all the cells, including the MCF-10F cells. The gain in the $8 \mathrm{p}$ region has been observed in many other human tumors (27). In $80 \%$ of the HBEC cells, gain of $8 q 24.1$ was accompanied by loss of 8 p11-21, suggesting the presence of an isochromosome of 8q. In fact, multiple copies of i(8)(q10) have been reported in several karyotypic studies of human lung cancer (28). Highest incidence at 8q24 were reported in lung cancer and lung cell cultures (29-32). The overexpression of 8q24.2 was reported in high grade cancers of breast and prostate (33). Also DNA amplification in the region $8 \mathrm{q} 22$-ter was reported in primary breast cancer tumors and their cell lines (34). Furthermore, amplification of MYC (8q24) has been associated with proliferation and unfavorable prognosis (35-37). Nephroblastoma overexpressed (NOV) gene are located in the specific region 8 q24.1. Over expression of a member of cysteine rich 61/connective tissue growth factor/nephroblastoma over-expressed (CYR61/ CTG/NOV) family growth regulators in invasive and metastatic human breast cancer cells has also been reported (38). It is known that CYR61 mediated diverse roles in development, cell proliferation and tumorigenesis (38). It was demonstrated that NOV protein associated with Notch 1 extracellular domain and inhibits myoblast differentiation via Notch signalling pathway (39). However, the exact mechanism by which this protein promotes carcinogenesis and aggressive breast cancer phenotype are still largely unknown.

Gain of $1 \mathrm{p}$ was the second most common genomic imbalance observed in all HBEC transformed cells. Genomic gains clustered to chromosome arm 1p were reported in $17 \%$ of human breast cancer in young women (40). In region $1 p$ are 1,204 genes, such as the tumor suppressor protein $\mathrm{p} 73$; genes related with DNA repair like growth arrest and DNAdamage-inducible, $\alpha$ (1p31.2-p31.1), mutS homolog 4 (E. coli) (1p31), DnaJ (Hsp40) homolog, subfamily B, member 4 (1p31.3); genes related with apoptosis such as tumor necrosis factor receptor superfamily, member 18 (1p36.3), DNA fragmentation factor, $45 \mathrm{kDa}$, $\alpha$ polypeptide (1p36.3-p36.2), caspase-9, apoptosis-related cysteine protease (1p36.3-p36.1).

The next gain that was observed in this study was in chromosome 5q21-ter, which was observed consistently 
from the transformed cell to the tumor cell line. This genomic aberration does not appear in the immortal cell MCF-10F. Additional changes in the tumor cell line BP-1-Tras were loss of 15q11-12 and gain at 5p15.3. In the cell line BP-1-Tras T J\#4 we have observed loss of 13q11-14, gain of 6q25-27, 18p11.3, 20p11 and 20q13.

Another important abnormality found during the transformation process of MCF-10F cells by BP is the loss of the entire chromosome 4,8p11-21 and 15q11-12. Several previously published reports have documented that allelic losses at chromosome 4 are present in several tumor types (41-48), although breast cancers have not been studied in detail. At least three discrete regions of frequent loss in $4 \mathrm{q}$ 33-34, 4q 25-26 and 4p 15.1-15.3 (48) have been identified in mesotheliomas and squamous cell carcinomas (49). It was reported that in the cultured tumor (breast cancer cell lines) and their corresponding tumors, the size of the deletions in chromosome 4 were similar (49). From the 20 regions of the whole chromosome 4 a total of 952 genes were expressed and reported to the human data base (BLAST The human Genome, http://www.ncbi.nih.gov/mapview), including one tumor suppressor gene, FAT tumor suppressor homolog 1 (4q34-35) directly related to breast carcinogenesis.

We also found a common loss in chromosome 8p11-21 after cell transformation, this region contains 194 genes (http://www.ncbi.nih.gov/mapview), including genes such as the bone morphogenetic protein 1, tumor necrosis factor receptor superfamily members $10 \mathrm{~b}, 10 \mathrm{a}, 10 \mathrm{c}, 10 \mathrm{~d}$, gonadotropin-releasing hormone $1(\mathrm{LHRH})$, cell division cycle associated 2, and clusterin or testosterone-repressed prostate message TRPM2. From these results we conclude that the loss of genes involved in chromosome 4 and in the region 8p11-21 are involved in the breast carcinogenesis process. Of interest is that the BP effects are irreversible in the HBEC and the same aberrations are maintained during the tumorigenesis process.

In conclusion, our panel of breast cancer cell lines provides a powerful tool for studying molecular and cytogenetic changes related to tumorigenesis. In addition to the histopathological and biochemical features reported previously $(21,25)$. DNA copy number changes detected in these cell lines will provide valuable data for investigation of tumor progression in vitro-in vivo and for more detailed mapping and isolation of genes implicated in breast cancer.

\section{References}

1. Slamon DJ, Clark GM, Wong SG, Levin WJ, Ullrich A and McGuire WL: Human breast cancer correlation of relapse and survival with amplification of the HER-2/neu oncogene. Science 235: 177-182, 1987.

2. Escot C, Theille C, Lidereau R, Spyratos F, Champeme MH, Gest $\mathrm{J}$ and Callahan R: Genetic alteration of the c-myc protooncogene (MYC) in human primary breast carcinomas. Proc Natl Acad Sci USA 83: 4834-4838, 1986.

3. Ali IU, Merlo G, Callahan R and Lidereau R: The amplification unit on chromosome llq13 in aggressive primary human breast tumors entails the bel-1, int-2 and hst loci. Oncogene 4: 89-92, 1989.

4. Theillet C, Adnane J, Szepotowski P, Simon MMP, Jeanateur P, Birnbaum D and Gaudray P: BCL-1 participate in the lq13 amplification found in breast cancer. Oncogene 5: 147-149, 1990.
5. Theillet C, Lidereau R, Escot C, Hutzell P, Brunet M, Gest J, Schlom J and Callahan R: Loss of a c-H-ras-1 allele and aggressive human primary breast carcinomas. Cancer Res 46: 4776-4781, 1986.

6. Lundberg C, Skoog L, Cavenee WK and Nordenskjold M: Loss of heterozygosity in human ductal breast tumors indicates a recessive mutation on chromosome 13. Proc Natl Acad Sci USA 84: 2372-2376, 1987.

7. Mackay J, Steel CM, Elder PA, Forest APM and Evans HJ: Allele loss on short arm of chromosome 17 in breast cancers. Lancet ii: 1384-1385, 1988.

8. Ali IU, Lidereau R and Callahan R: Presence of two members of c-erbA receptor gene family (cerbAp0 and C-erbBA2) in smallest region of somatic homozygosity on chromosome 3p21-p25 in human breast carcinoma. J Natl Cancer Inst 81: 1815-1820, 1989.

9. Chen LC, Dollbaum C and Smith H: Loss of heterozygosity on chromosome lq in human breast cancer. Proc Natl Acad Sci USA 86: 7204-7207, 1989.

10. Callahan R and Campbell A: Mutations in human breast cancer: an overview. J Natl Cancer Inst 81: 1780-1786, 1989.

11. Sato T, Saito H, Swensen J, et al: The human prohibitin gene located on chromosome 17q21 is mutated in sporadic breast cancer. Cancer Res 52: 1643-1646, 1992.

12. Chen LC, Kurisa W, Ljung BM, Goldman ES, Moore D and Smith HS: Heterogeneity for allelic loss in human breast cancer. J Natl Cancer Inst 84: 506-510, 1992.

13. Genuardi M, Tsihira N, Anderson DE and Saunders GF: Distal deletion of chromosome lp in ductal carcinoma of the breast. Am J Hum Genet 45: 73-892, 1989.

14. Cropp CS, Lidereau R, Campbell G, Champene MH and Callahan R: Loss of heterozygosity on chromosomes 17 and 18 in breast carcinoma: two additional regions identified. Proc Natl Acad Sci USA 87: 7737-7741, 1990.

15. Sata T, Tanigami A, Yamakawa K, Aklyama F, Kasmi F, Sakamoto G and Nakamura Y: Allelotype of breast cancer: cumulative allele losses promote tumors progression in primary breast cancer. Cancer Res 50: 7184-7189, 1990.

16. Sata T, Akiyama F, Sakamoto G, Kasumi F and Nakamura Y: Accumulation of genetic alterations and progression of primary breast cancer. Cancer Res 51: 5794-5799, 1991.

17. Russo J, Barnabas N, Zhang PL and Adesina K: Molecular basis of breast cell transformation. Radiat Oncol Investig 3: 424-429, 1996.

18. Russo J, Calaf G, Sohi N, Tahin Q, Zhang PL, Alvarado ME, Estrada $S$ and Russo IH: Critical steps in breast carcinogenesis. Ann N Y Acad Sci 698: 1-20, 1993.

19. Hu YF, Russo IH, Zalipsky U, Lynch HT and Russo J: Environmental chemical carcinogens induce transformation of breast epithelial cells from women with familial history of breast cancer. In Vitro Cell Dev Biol 33: 495-498, 1997.

20. Russo J, Calaf G and Russo IH: A critical approach to the malignant transformation of human breast epithelial cells with chemical carcinogens. Crit Rev Oncog 44: 403-417, 1993.

21. Calaf G, Russo J and Alvarado ME: Morphological phenotypes in neoplastic progression of benz(a)pyrene treated-breast epithelial cells. J Submicrosc Cytol Pathol 32: 535-545, 2000.

22. Soule HD, Maloney TM, Wolman SR, Peterson WD Jr, Brenz R, McGrath CM, Russo J, Pauley R, Jones RF and Brooks SC: Isolation and characterization of a spontaneously immortalized human breast epithelial cell line, MCF-10F. Cancer Res 50: 6075-6086, 1990.

23. Tait L, Soule H and Russo J: Ultrastructural and immunocytochemical characterizations of an immortalized human breast epithelial cell line MCF-10. Cancer Res 50: 6087-6094, 1990.

24. Calaf $\mathrm{G}$ and Russo J: Transformation of human breast epithelial cells by chemical carcinogens. Carcinogenesis 14: 483-492, 1993.

25. Calaf G, Zhang PL, Alvarado MV, Estrada S and Russo J: C-Haras enhances the neoplastic transformation of human breast epithelial cells treated with chemical carcinogens. Int J Oncol 6: 5-11, 1995.

26. Kallioniemi OP, Kallioniemi A, Sudar D, Rutovitz D, Gray JW, Waldman $F$ and Pinkel D: Comparative genomic hybridization: a rapid new method for detecting and mapping DNA amplification in tumors. Semin Cancer Biol 4: 41-46, 1993.

27. Rooney JD, Murray GI, Stevenson DA, Haites NE, Cassidy J and McLeod HL: Comparative genomic hybridization and chromosomal instability in solid tumours. Br J Cancer 80 : 862-873, 1999. 
28. Parada LA, Hallen M, Tranberg KG, Hagerstrand I, Bondeson L, Mitelman F and Johansson B: Frequent rearrangements of chromosomes 1,7 , and 8 in primary liver cancer. Genes Chromosomes Cancer 23: 26-35, 1998.

29. Fujiwara Y, Monden M, Mori T, Nakamura Y and Emi M: Frequent multiplication of the long arm of chromosome 8 in hepatocellular carcinoma. Cancer Res 53: 857-860, 1993.

30. Zimonjic DB, Keck CL, Thorgeirsson SS and Popescu NC: Novel recurrent genetic imbalances in human hepatocellular carcinoma cell lines identified by comparative genomic hybridization. Hepatology 29: 1208-1213, 1999.

31. Tabor E: Tumor suppressor genes, growth factor genes, and oncogenes in hepatitis B virus-associated hepatocellular carcinoma. J Med Virol 42: 357-365, 1994.

32. Balsara BR, Pei J, De Rienzo A, et al: Human hepatocellular is characterized by a highly consistent pattern of genomic imbalances, including frequent loss of 16q23.1-24.1. Genes Chromosomes Cancer 30: 245-253, 2001.

33. Tan JMM, Tock EPC and Chow VTK: The novel human MOST-1 gene exhibits tissue specific expression maps to chromosome 8q24.2 and is overexpressed/amplified in high grade cancer of breast and prostate. Mol Pathol 56: 109-115, 2003.

34. Larramendy ML, Lushnikova T, Bjorkqvist AM, Wistuba II, Virmani AK, Shivapurkar N, Gazdar AF and Knuutila S: Comparative genomic hybridization reveals complex genetic changes in primary breast cancer tumours and their cell lines. Cancer genet Cytogenet 119: 132-138, 2000.

35. Persons DL, Borelli KA and Hsu PH: Quantitation of HERs/neu and c-myc gene amplification in breast carcinoma using fluorescence in situ hybridization. Mod Pathol 10: 720-727, 1997.

36. Berns EM, Klijn JG, Smid M, van Staveren IL, Look MP, van Putten WL and Foekens JA: TP53 and MYC gene alterations independently predict poor prognosis in breast cancer patients. Genes Chromosomes Cancer 16: 170-179, 1996.

37. Misukami Y, Nonomura A, Takizawa T, Noguch M, Michigishi T, Nakamura S and Ishizaki T: N-myc protein expression in human breast cancer: prognostic implications. Anticancer Res 15: 2899-2905, 1995.

38. Menendez JA, Mehmi I, Griggs DW and Lupu R: The angiogenic factor CYR61 in breast cancer: molecular pathology ad therapeutic perspectives. Endocr Relat Cancer 10: 141-152, 2003.

39. Sakamoto K, Yamaguchi S, Ando R, Miyawaki A, Kabasawa Y, Takagi M, Li CL, Perbal B, Katsube K: The nephorblastoma overexpressed gene $(\mathrm{NOV} / \mathrm{ccn} 3)$ protein associate with Notch 1 extracellular domain and inhibits myoblast differentiation via Notch signaling pathway. J Biol Chem 277: 29399-29405, 2002.
40. Weber-Mangal S, Sinn HP, Popp S, Klaes R, Emig R, Bentz M, Mansmann U, Bastert G, Bartram CR and Jauch A: Breast cancer in young women ( $\leq 35$ years): genomic aberrations detected by comparative genomic hybridization. Int J Cancer 107: 583-592, 2003.

41. Polascik TJ, Cairns P, Chang WY, Schoenberg MP and Sidransky D: Distinct regions of allelic loss on chromosome 4 in human primary bladder carcinoma. Cancer Res 55: 5396-5399, 1995.

42. Buetow KH, Murray JC, Israel JL, London WT, Smith M, Kew M, Blanquet V, Brechot C, Redeker A and Govindarajah S: Loss of heterozygosity suggests tumor suppressor gene responsible for primary hepatocellular carcinoma. Proc Natl Acad Sci USA 86: 8852-8856, 1989.

43. Vogelstein B, Fearon ER, Kern SE, Hamilton SR, Preisinger AC, Nakamura Y and White R: Allelotype of colorectal carcinomas. Science 244: 207-211, 1989.

44. Hammoud ZT, Kaleem Z, Cooper JD, Sundaresan RS, Patterson GA and Goodfellow PJ: Allelotype analysis of esophageal adenocarcinomas: evidence for the involvement of sequences on the long arm of chromosome 4. Cancer Res 56: 4499-4502, 1996.

45. Larson AA, Liao SY, Stanbridge EJ, Cavenee WK and Hampton GM: Genetic alterations accumulate during cervical tumorigenesis and indicate a common origin for multifocal lesions. Cancer Res 57: 4171-4176, 1997.

46. Loughran O, Clark LJ, Bond J, Baker A, Berry IJ, Edington KG, Ly IS, Simmons R, Haw R, Black DM, Newbold RF and Parkinson EK: Evidence for the inactivation of multiple replicative life span genes in immortal human squamous cell carcinoma keratinocytes. Oncogene 14: 1955-1964, 1997.

47. Pershouse MA, Elnaggar AK, Hurr K, Lin H, Yung WKA and Steck PA: Deletion mapping of chromosome 4 in head and neck squamous cell carcinoma. Oncogene 14: 369-373, 1997.

48. Shivapurkar N, Virmani AK, Wistuba II, Milchgrub S, Mackay B, Minna JD and Gazdar AF: Deletions of chromosome 4 at multiple sites are frequent in malignant mesothelioma and small cell lung carcinoma. Clin Cancer Res 5: 17-23, 1999.

49. Shivapurkar N, Sood S, Wistuba II, et al: Multipe regions of chromosome 4 demonstrating allelic losses in breast carcinomas. Cancer Res 59: 3576-3580, 1999. 